\title{
CONTENTS (continued)
}

\section{PAGE PAGE}

NEWS OF SCIENCE AND TECHNOLOGY

Tenth International Conference on High-Energy Physics. A. A. Tyapkin ... . . . . 8180

International Conference on Instrumentation for High-Energy Physics. A. A. Ty a pkin . . $85 \quad 83$

[Plans for Atomic Power Station Reactors . . . . . . . . . . . . . . . . . 86]

[Equipment of the Atomic Power Station in Dungeness

Source: Nuclear Energy 14, $408(1960) \ldots \ldots \ldots \ldots \ldots \ldots \ldots \ldots \ldots \ldots \ldots$ 9. $\ldots \ldots \ldots$

[Construction of the Reactor in Chinon, France

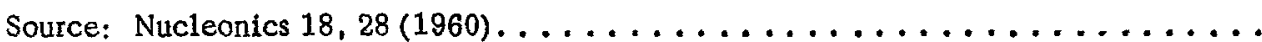

[Trends in Developments in the Uranium Industry in France

Source: $R$. Bodu, Recent Developments in the Chemical Treatment of Uranium Ores

in France, International Mineral Processing Congress (London, 1960) . . . . . . . .

A Device for the Measurement and Automatic Control of Liquid Discharge by Means of

Radioactive Radiation. N. N. Shumilovskii and $\mathrm{Yu}$. V. Gushchin..... 8893

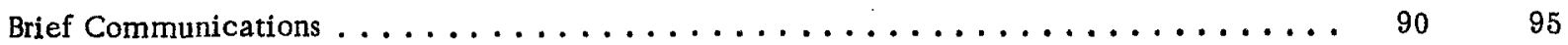

BIBLIOGRAPHY

New Literature. Books and Symposia . . . . . . . . . . . . . . . . . . . . . 9199

Note. The Table of Contents lists all materials that appears in Atomnaya Énergiya. Those items that originated in the English language are not included in the translation and are shown enclosed in brackets. Whenever possible, the English-language source containing the omitted reports will be given. Consultants Bureau Enterprises, Inc.

ERRA TA

VOL. 9, NO. 2

Page

655

620
Reads

$C=C_{0} 1+\left[\frac{E(0)+E(d)}{2 E_{0}}\right]$

Charge in grams of elementary boron per $1 \mathrm{~cm}^{2}$ of column cross section per $1 \mathrm{hr}$ receiver

Temperature in re ceiver of column, ${ }^{\circ} \mathrm{C}$
Should Read

$C=C_{0}\left[1+\frac{E(0)+E(d)}{2 E_{0}}\right]$

Charge in grams of ele mentary boron per $1 \mathrm{~cm}^{2}$ of column cross section per $1 \mathrm{hr}$

Temperature at top of column, ${ }^{\circ} \mathrm{C}$ 